\title{
A Tool for Understanding the Transformation within Higher Education Administration Processes: International Exchange Programs (Erasmus Exchange Program)
}

\author{
Dr. Esra Ebru MAVí ${ }^{1}$
}

\begin{abstract}
Globalisation has shown its effect through the transformation experienced in economic, social and political areas at the end of $20^{\text {th }}$ century. Globalisation has had a major impact on in public administration area apart from focusing the argumentation on questioning the existence of a state at the last degree. The change in public administration becomes concrete by analysing service sector. Education sector is one of the most significant areas in which the change in public sector seems visible in addition to characteristics of labour. Education services organized by government in Turkeyis discussed through the impact of neoliberal policies. In the study, the transformation of higher education administration, a part of education system, will be discussed within the framework of New Public Service Administration notion.
\end{abstract}

Keywords: Public services, public administration, education policy, academic mobility, Erasmus Exchange Program

\section{INTRODUCTION}

Globalisation has caused great transformation in all fields that state has been organised on, particularly economic, politic and social. This transformation has caused differences in quality and quantity in the services that state has done. The effect of globalisation and the increase in variety and intensity of public services have brought the demand for reorganisation in the understanding of public administration that can be defined as style of state's social and economic organisational form.

The effect which globalisation had created on public administration is embodied when it is analysed through service sectors. Globalisation has caused a great transformation in labour-intensive service sector as well as in education field which is one of the most important dynamics of social change/transformation. Education sector, unlike other labour-intensive service sectors, is a place where investment and expense are intense for reaching goals but outcome takes time. Therefore this field poses as an element of risk for policy makers usually

Beginning from the foundation of the Republic, the education sector, run and organised by the state, has always searched for developing quality and performance focused education system with its tendency for internationalisation, particularly beginning from 1970s. One of the important devices in internationalisation of Turkish higher education system is international mobility programs.

International mobility programs have found application field in higher education systems with reasons such as increasing quality and intercultural interaction along with globalisation. Those programs aim to integrate students, instructors and office staff to international system by increasing their quality and productivity.

It has been seen that mobility programs have only been analysed and evaluated with "focus on education" when literature researches on higher education systems and international mobility programs are analysed. International mobility programs will be focused on the changes they made in "education service sector process" beyond being considered as a device that belongs to education service in globalisation process and understanding the transformation that they made in "education sector."

This study consists of three chapters. In the first chapter, impact of globalisation in the world and Turkey on public administration; in the second chapter impact of globalisation specific to education and higher education system and international mobility programs (Erasmus Exchange Program) as tools; in the third chapter assumed transformation in administrative processes (personnel, technical equipment, methods/technics used in administration, organisational structure and duties) of state higher education institutions in Ankara (Ankara University, Gazi University, Hacettepe University, Middle East Technical University) will be approached. The study will be finalised with findings and result chapters. It is considered that focusing on

${ }^{1}$ Expert, Council of HigherEducation, TURKEY, esraebrumavi@ gmail.com

DOI: $10.9790 / 0837-22050198107 \quad$ www.iosrjournals.org


impact of international mobility programs on administrative processes of higher education institutions with executives will be a genuine example for detecting the transformation in Turkish public administration.

\section{Impact of Globalisation on Public Administration in the World in Turkey}

Education service sector which includes higher education field constitutes one of the important pieces of public administration. Accurate analysis of transformation in higher education administration process is connected to understanding the transformation that occurs with the impact of "globalisation" in public administration field. Even though globalisation is associated with economy, in general opinion, it is, actually, used to define international system today.

Economic crisis that capitalism experienced in 1920s had been overcome during restructuring process of world economies after World War II. Bases of policies, founded theoretically by Keynes, ground on welfare state. State's intervention in economy for providing same amount of access for services for all people is the basis (Özşuca, 2001:9). Nationalisation, creation of national health services, popularisation of public education, public housing in great amounts and social aid system were put in place by economic and social reform programs (Hall and Jacques, 1995:37). In accordance with Keynesian economy policies, service fields such as health and education are run under state's responsibility.

The welfare state period, began after World War II and ended in 1970s after going through a crisis, was an important turning point. Constant increase of social welfare applications and its being an important burden on public budget constituted the most important topics of critics and debates (Bulut, 2003:173-174). This thought brought new debates regarding basic service fields, which are run by the state, such as education and health should not be run by the state.

Constant and comprehensive state reforms, which were evolved into "governance" concept by rationalisation of public sector especially began in 1970s and fastened in 1980s, are witnessed. Reform studies in education services actually constitute a piece of reform studies in the state (Akbulut, 2007:150-155).

Neo-liberal policies that constitute the starting point of globalisation caused great transformations in social and economic organisation forms in the world and Turkey and brought debates on definition of the role of state on the world up. It is emphasised in the ongoing debates that all institutions and organisations, particularly economic and social, that belong nations are going under a reconstruction by worldly institutive structures. This describes "the reconstruction in the state" which is heard often in last years. Reconstruction policies are basically consisted of minimising public services in order to restrict public expenses, reconsideration of social security policies and personnel policies that are based on flexible employment and labour system.

The transformation in public administration field basically occurs through localisation and liberalisation policies. Two main frames are needed for analysis of mentioned policies: The first is content and analysis of academic studies that are carried out in public administration field. The other is reflection of transformation in public administration field. The transformation in the understanding of public administration can be approached in application with basically national/international policy files and documents and, secondly, often organisation of public sectors that are structured in accordance with those policy documents. The above mentioned two main frames signal a dynamic process that ignites each other.

All approaches that constitute Taylor's Scientific Understanding of Administration, Fayol's Process and Function Approach and Weber's Bureaucracy Model are pieces of scientific administration when the history of public administration is studied. New Public Administration Understanding replaced the scientific and modern public administration understanding, beginning from 1970s in accordance with globalisation and neoliberal policies in the world. Decentralisation, subsidiarity, competition, availability to choose, customer centricity and flexible applications came forward with the replacement of New Public Administration Understanding with wide scaled, hierarchical organised bureaucracy features of traditional public administration understanding (Bayraktar, 2003:561-572).

New Public Administration Understanding has been referred as School of Public Management, Professional Management and New Scientific Administration in scientific studies. This approach, theoretic in field of public science, constitutes the focus of debates on differentiation of public administration and management in itself. Public Management Approach and, later, New Public Management Approach suggest a third way based on the basis of management of public administration field with manager understanding. The new administration notion is established on five basic claims:

1. Social progression can take place through constantly increasing economic productivity.

2. Productivity increase can be made through an increasing intensive communication and organisational technology use.

3. Implementation of the technology can be carried out by labour force within productivity ideal and discipline.

4. Productivity, planning, implementation and evaluation can be realised by a quality and professional managing group. 
5. The administrators should be allowed an action area to fulfil this process. The last trait is defined as freely management and the right to manage (Üstüner, 2000:15-31).

The second frame in understanding the occurred transformation in public administration field looks at the reflections of transformation in applications. Debilitation of nation states' capacity of making policies in some basic fields in globalisation process occurs in parallel with strengthening of powers of supra-state organisations (Farazmand, 2001:258). Lately, prescriptions offered by global organisations such as World Bank (WB), International Monetary Fund (IMF), World Trade Organisation (WTO), United Nations (UN) and European Union (EU) have been decisive in developing/under developed countries' policy processes. Frame texts, as referred in structural adjustment programme in public administration, find reply in public administration in national legislation and administrative processes or in applications and qualifications such as transformation of public administration.

Adjustment studies in national legislation with the impact of globalisation -which has been thought to be occurred, in literature, sometimes because of need or necessity, force/imposition and often criticised- signals to a constantly transforming and changing processes rather than a stable situation (Kapucu and Kösecik, 2003).Structural adjustment programmes that have application devices in developing/under developed countries have two important aspects regarding public administration: 1) Directing targets and strategies of national plan and programmes feature, 2) Impact of direct organisation public sector and public administration, and changing work principles, forms of employment and functions. Importance of agreements is resulted from being applied in great amount in addition to those qualifications (Güler, 1995:28).

Each of global organizations' decisiveness and field of interest on governments' public policies show differences. Member nations of World Trade Organisations, including Turkey, make a commitment by signing a series of agreement to allow roaming of imported goods and service in their domestic market and removing or decreasing protective obstacles, i.e. customs, in front of trade. General Agreement on Trade in Services (GATS) constitutes one of the juridical texts that this study bases on.

GATS is the first multilateral agreement that puts forth basic concepts, rules and principles regarding international service trade. This agreement's importance on operation of global economy for easily running services sector is emphasised (http://www.ekonomi.gov.tr, 2016).GATS can basically be seen as an agreement that regulates running of public services, which are run by state, by private sector. Informatics/communication, environment, education, health, transportation, energy, banking and tourism services are liberalised with GATS (http://www.ekonomi.gov.tr, 2016). With this policy, WTO makes public services subject to service global free trade; EU makes way to those policies by adjustment laws that it made path for its target countries; OECD prepares reports/regulating reform programs for administration of policy process; WB provides financial fund for those processes.

OECD, which plays a decisive role in many countries', including Turkey, public policies, is a union of 30 members for democracy and market economy (www.oecd.org, 2016).OECD's work on globalisation and this concept, which was used frequently in the frame of regulatory reform programme which it accepted in 1997, covers basically the process in building a new state structure named as regulator state (Bayramoğlu, 2003:143144).

European Union is a politic and economic organisation that is consisted of countries in European Continent. In this regard it continues to its attempts to reach politic integration, aimed at its European Union goal, by becoming one market and, thus, going through economic integration. One Market, which is the main element of the union and EU's goal, needs actualisation of four important freedoms as pre-condition. Those are the freedom of roaming of goods, persons, services and capital inside Union's borders (Tekinalp and Tekinalp, 1997:34).

Reconstruction of state structures and business manners of candidate and member countries of EU by $\mathrm{EU}$ is at stake without minding the difference between public and private sector. Reconstruction of public administration is aimed at with basic subjects such as public administration reform, public finance management and control, decentralisation and strengthening of institutional capacity. Especially, decrease of bureaucracy, transparency in public administration and accountability are targeted. Policies that EU predicted for candidate countries in public administration field reflect on candidate country Turkey's public policy processes. Therefore, Progress Reports (http://www.kalkinma.gov.tr/, 2016) become one of the basic texts in Turkey's reconstruction of public administration in addition to Accession Partnership Document and National Programme.

\section{The Place of International Exchange Program (Erasmus Exchange Program) in the Impact of Globalisation on Education and Higher Education Systems}

Applications such as search for new markets and competition, depending on worldly deepened economic crisis, replaced basic concepts and related applications, after mid-1970s, such as general welfare and social justice, which were referred as social state or, also known as welfare state's, and dominant in policies of governments until mid-1970s. While many public service fields, from health to education, are run by state, by 
basing on general interest, in social state understanding, services sector has become an attractive market with neo-liberal policies.

Neo-liberal policies come to living with applications such as politic and economic prescriptions or stabilisation/adjustment programmes suggested by above mentioned organisations such as WTO, IMF and WB to governments. Application of those programmes occurs through agreements, such as MAI, MIGA and GATS, signed between international organisations and governments. Predicted structural transformation in other sectors in those agreements and programmes has shown itself in education sector as well. Education policies of states (Oğuzkan, 1976:84) has transformed and become open to external impacts depending on above mentioned transformation of public administration in globalisation process.

World Bank is the most effective organisation, especially lately, that shapes education policies in the world and Turkey. The first education subjected agreement of World Bank is education loan to Tunisia in 1962 (http://www.bankinformationcenter.org/ , 2016).One of the devices that World Bank uses in shaping public policies, apart from sectoral loans, is the reports that are named as Country Assistance Strategy (CAS) which it had begun in 1998. Those reports are three-year-study-plans that World Bank prepares for approached country. CAS document basically has aim to give loan in the mentioned country and, in addition, technical support is also provided.

Liberalisation of many service fields has come existence by emphasising the increase of tradability of customer choices (http://www.ekonomi.gov.tr/ , 2016), technical and adjusting innovations and services transformed by GATS. Education sector is one of the most important service fields that is expected/imposed to adjust in market order within GATS. Education has transformed in to a service field, being subject to trade, in global order. This transformation signals a process that education moves away from national matter to integrate in international structure.

Higher education has been going through an important transformation all over the world for the last twenty years, especially depending on the above mentioned developments with the impact of GATS agreement. Countries have put effort in to comparing their higher education systems, finding mutual solutions to common problems and especially competing with America's and Japan's axes policies. Therefore, they have come together and started Bologna Process to create European Higher Education Area (Yuksekogretim Kurulu, 2010:2).

Bologna Process revealed itself, with Sorbonne Manifesto, after a meeting held by France, Italy, Germany and England in Sorbonne, in 1998. The basic idea of the Manifesto is to create a mutual higher education area in Europe. The Bologna Process has officially started after a meeting which was held in Bologna, Italy in 1999.Basic goals in the so-called are as in the following: 1-To generate easily comprehensible and comparable higher education diplomas and degrees; 2-To transfer into tow-tier system as bachelor and master in higher education; 3- To implement European Credit Transfer System (ECTS); 4- To foster and expand student and academic staff mobility; 5- To implement and expand a quality assurance network in higher education; 6To develop a European dimension in higher education (Yuksekogretim Kurulu, 2010:3).

Main problems for opening higher education to international markets are the problems that students and teachers face while going abroad and entering the countries that they will get education service from. At this point, two important subjects need to be emphasised. The first is that, as a result of coming forth of education's international dimension, labour (student, instructor) mobility (later mobility programs aimed at removing obstacles in front of labour mobility) since it is a service sector and the second is that the works on adjustment for recognition of diplomas/grades as documents for received education.

It is predicted that easing of free roaming of services with some mechanism in the world, especially with EHEA created for integration of higher education field in European Area to global system. Those mechanisms are basically recognition of diplomas and accreditation. Recognition of diplomas came forth first in Europe beginning from early 1950s. However, finding application fields by adjustments in European region, regarding recognition of documents, came into existence with Lisbon Agreement (on 11 April 1997).

Under Lisbon Recognition Agreement's Application Mechanism headings (X.1. Clause) NARIC (National Academic Recognition Information Centres-1984) and ENIC (European Network of Information Centres-1994) are defined as recognition networks (http://portal.unesco.org/, 2016). NARIC is a European Commission Institution that develops diplomas and education processes, which are received from a foreign country, academically. ENIC is a communication network that is used for creating mutual approach and mobility in the field of recognition of academic sufficiency (Yuksekogretim Kurulu, 2010:44).

Diploma Supplement and European Credit Transfer System (ECTS) are the parts of Bologna Process that aims to create EHEA, including Turkey. Diploma Supplement is a supplement document to higher education diploma. Diploma Supplement gives information about graduate student's content, level and structure of completed academic work and higher education system of mentioned country (Aykin and Oguz, 2003:372). ECTS is another element that aims to remove problems that are faced in recognition, since countries have 
different higher education systems. ECTS was used, first, to transfer credits in mobility activities in Erasmus Program and, later, as credit accumulating system (Yuksekogretim Kurulu, 2010:43-44).

GATS's applications in the education sectors of countries and Turkey and solutions for the problems that they face in liberalisation process of education can be seen in the basic targets of Bologna Manifesto. Manifesto aims at removing/minimising the obstacles in student/academic personnel mobility, activating student exchange programs and recognising gained diplomas and degrees. Reconstruction and adjustment for reshaping of European Area with education, especially with higher education, find reflection as European Research Area (ERA). ERA aims at removing all the obstacles in front of free roaming of services through recognition of diplomas and accreditation mechanisms. Primary targets and activity areas in after 2010 were emphasised in Leuven Ministers Conference Manifesto in April 2009. In this regard, in addition to above mentioned main targets, mobility, social dimension and lifetime learning were added into activity areas of higher education for the next ten years (Yuksekogretim Kurulu, 2010:10).

"European Strategy 2020: European Strategy for Intelligent, Sustainable and Inclusive Growth" (EU 2020), continuation of Lisbon Agreement which promotes cooperation of education in European Union, presented by President of European Commission Jose Manuel Barroso, set primary targets for education. Five main targets and seven main enterprises to make those targets happen were determined for 2020 Europe. Education 2020, which is the main frame of European cooperation in education, built on outputs from "Education 2010" itinerary and strategy basis of EU 2020, was prepared. There are four main goals of Education and Training 2020 in the Declaration of European Commission titled as "Strategic Framework for Collaboration in Education and Training", one of which is realisation of mobility considered together with lifelong learning. $20 \%$ of increase in higher education mobility has been targeted in this regard (http://www.ab.gov.tr/ , 2016).

Transformation in education sector, one of the most important service fields that globalisation process affected in the world, showed its impact in Turkey, as well. Turkey has acceded to agreements on international level and made some adjustments aiming at adjusting education policy texts. World Bank is the most effective international organisation that shapes Turkey's public policies and education field in sectorial level. World Bank's intervention in education services began in 1971 (USD 13.5 million) Turkey and World Bank has signed 8 agreements under education heading until today (http://www.worldbank.org/, 2016).

GATS, Lisbon Agreement and Bologna Process are three of the important legal regulations that Turkey was joined in. Turkish education policy has been shaped with the impact of above mentioned international regulations. Fast transformation of the world after 1980 made way to great changes in services sector, including education services. Turkey signed GATS as founder member; Final Act, which came into force in 1 January 1995, was approved in GNAT in 25 February 1995 and membership of our country to World Trade Organisation was declared officially in 26 March 1995. Turkey made a commitment on education sector with GATS agreement: 1-primary, middle and other education services, 2-higher education services (http://www.ekonomi.gov.tr/, 2016).

Turkey signed Lisbon Recognition Agreement act in 01.12.2004 and the Agreement came into force in 01.03.2007. Changes in Abroad Higher Education Diplomas Regulation were made for adjusting the national legislation with the Agreement (Yuksekogretim Kurulu, 2010:40).Diploma Supplement and ECTS, two important devices in internationalisation of higher education system, were mentioned separately in Lisbon Agreement. Moreover, ENIC-NARIC recognition networks were placed in the mentioned Agreement. Application of Diploma Supplement began in 2005-2006 education year in Turkey according to decision that was taken in Higher Education Institution' General Meeting in 11.03.2005. According to this, higher education institutions are obliged to give Diploma Supplement in widely spoken European language in addition to diplomas of graduate students, beginning from 2005-2006 academic year (Yuksekogretim Kurulu, 2010:42).

ECTS is one of the most work fields in Lisbon Agreement. Many universities in Turkey have put an effort to adjust their credit and mark system to ECTS conditions in recent years. In this regard ECTS institution coordinators and separate ECTS coordinators for each faculty were designated for being responsible both application of ECTS in universities and informing students about ECTS.

ENIC/NARIC Centre, Turkey joined in organisation of Higher Education Institution. The Centre has worked as a part of ENIC/NARIC communication network since 2003. Representatives of ENIC/NARIC centres, working under this network, come together regularly and do mutual works on recognition of diploma/grades. ENIC/NARIC Centre, Turkey informs internal/external partners about recognition of diplomas, degrees and other proficiencies gained at foreign country; higher education system of foreign countries and Turkey and illuminating questions for those who want to receive education abroad by exchanging ideas with other ENIC/NARIC Centres in the communication network (Yuksekogretim Kurulu, 2010:41).

First works aiming at creating Frame of Higher Education Proficiencies were done after Ministers meeting which was held by Higher Education Council in Bergen, in 2005 for creating Frames for National Proficiencies. Higher Education Proficiencies Commission, which was first created in 2006, continued its works until 2008. Higher education proficiencies, except for two-year degree, arts and vocational proficiencies, were 
accepted with Resolution of General Assembly in 21.05.2009. Full approval of Frame of Higher Education Proficiencies by Higher Education Council took place with resolution of General Assembly in 21.01.2010 (Yuksekogretim Kurulu, 2010:23).

Higher Education Quality Standard Regulation, which was published in Official Gazette, no. 29423, dated 23 July 2015, and came into force, was removed. In this regulation's frame, Higher Education Quality Council was founded and started its works. Turkey joined in Bologna Process, which was created for adjusting higher education on local, national and global level, also covering European Union Area, in 2001 (Yuksekogretim Kurulu, 2010:4). Bologna Process predicts 3 degree higher education system. Undergraduate education is accepted as $1^{\text {st }}$ degree; post graduate as $2^{\text {nd }}$; doctorate as $3^{\text {rd }}$ in this system that covers European Higher Education Area. This system was present even before Bologna Process.

Paving way for the mobility in higher education is emphasized as the aim in the change that is created by globalisation in higher education system. However, as their structure required, mobility programs are rather functional device than to be aim for higher education systems and administrations due to their integration with international system.

Reform or re-formation works carried out in public administration are complex process. Analysis of the transformation in management of the sector could be enabled through four main classifications:1- Human beings; 2- Materials, money, equipment and facilities; 3- Methods and techniques used in the management; 4Organisational structure and duties (Payasloglu, 2003:431).

It is possible to analyse the transformation of the sector occurred during its management process under four main classifications. Transformation occurred in the management process can be seen and understood better with the above concatenated classification.

Dual structure is the subject matter when dealing with the higher education institution s administrative processes. In accordance with the law no. 2547 under the title of 'University Bodies' taking academic decisions in higher education institutions is subject to rector, vice rector, senate, the university administrative committee and the highest chief rector of the faculty. Vice rectors are placed on the second rank of the hierarchy after the rector. Secretary General, assistant secretary-general, head of departments and departmental managers are placed respectively in administrative structuring. In the law no. 2547 bodies of the university are concatenated as rector, vice rector, senate, university administrative committee, faculty, dean, vice dean, faculty committee, faculty administrative committee. In the law no. 2547 secretary-general, head of departments and managers are addressed under the title 'Administrative Sections.' In the mentioned law, secretary-general is defined as the head of the central administration organization. Administrative processes in the higher education institutions present a different structure than those in classic service sector. In the applicable law and enforcement, there is a hesitant and uncertain situation of the academic and administrative official staff in the higher education administrative processes. This situation does not remove the strict hierarchical bureaucratic structure in the administration process. Although the duty and responsibilities of the administrative and academic staff are explained in the applicable law, in practice larger and higher sanction power field has given to the academic staff in higher education management process, which is not stated clearly in the law for the administrative staff.

\section{Analysis of the Impact of Erasmus Exchange Programme on the Transformation of Organisational Processes at Higher Education Institutions}

This section discusses the change created by administration process regarding Erasmus Exchange Program on the higher institutions administration processes with reference to the public administration processes. The reason why Exchange Program discussed in the study is the assumption of that higher education administration system mobility programs can be striker devices which are one of the most important service sectors reflecting the change in the public administration. The reason for this presupposition arisen from the structure of the mobility programs. Programs have the important characteristic as a device of the higher education systems of the countries and their interaction with administration processes.

There are mainly two international mobility programs in Turkey. The one is Erasmus Exchange Program and the other is Mevlana Exchange program. Erasmus Exchange Program is discussed in the study. The reason for that Mevlana Exchange Program has a 3 years of application history. However because of Erasmus Exchange Program having a date long way back (Turkey's involvement to the Program was in 2003) it is assumed that the Program created an executive culture.

Came into effect by January 1st 2014, Erasmus+ Program is the general name for the roof program which consists supports for different age and target groups in the fields of education, youth, and sport. Within the Erasmus+ Program, as are the previous programs, support for the higher education, vocational education, adult education and youth education are in progress, in addition to this grant support is also provided to the projects in the sport field. Erasmus+ Program contains the fields of education, teaching and sport. The main reason for giving the Erasmus+ name to Program is to take advantage of the popularity of previous Erasmus Program which is more widely acknowledged in the public opinion and strongly identified with the studying 
abroad and European corporation (http://www.ua.gov.tr, 2016).The executive body of the European Union in the execution of the Erasmus+ Program is the organization that ensuring the coordination between European commission and higher education institutions is mentioned in the regulation as 'Centre for European Union Education and Youth Programs' but it is known as 'national agency'.

Almost in every higher educational institution Erasmus Exchange Program is conducted by the Erasmus Offices created under the roof of international relations units within conditions and process schedule in the guideline published European commission every year. The processes of the Programme can be listed as in the following:1-Announcement of the Exchange applications; 2- Receiving applications for Exchange; 3Evaluation of applications; 4- Announcement of results of the evaluation.

In this study an in-depth interview have been made with the Erasmus Coordinator and specialist of the four government higher education institutions in Ankara (Ankara University, Hacettepe University, and Middle East Technical University). The questions prepared for the interview are based on four categories (staff, equipment and supplies, the methods and technic used in management) with the expectation of detecting a change in management. The answers of the questions are obtained through the method of face-to-face interviews and taking notes. After the interview, noted answers are computerized and confirmed to the related ones via e-mail.

\section{FINDINGS AND CONCLUSION}

From the in-depth interview question under four categories within the study,

1- ) People: There are six questions in this title. Almost all of the coordinators and office staff have given the same answers about their designation condition (educational status, foreign language, period of service). All of the coordinators are stated that there are no written criteria to be commissioned as coordinator or office staff. They indicated that bachelor's degree is sufficient and the experience and sufficient linguistic level are unwritten criteria. All of the coordinators are commissioned by the rectors. They stated that there is no staff degree such as coordinator and there is no official procedure for resignation in case of expiration their commissions. It is stated that there are contracted staff among the Hacettepe University and METU and also academic staff working at the Ankara University and METU.

It is stated that the difference in employment types and contracted status of the staff is hindering the office work and sustainability. It is stated that the there is no special application for the staff to benefit from the Program yet METU and Hacettpe stated that long-served staff who has not participated in the Program before are privatized.

METU and Gazi Universities are stated their staff benefited from the Program within the Erasmus Staff as to in-service training for staff. Ankara University separated the trainings as internal and external. Internal training are separated as the trainings given by the National Agency and internal training as the trainings given by the office (computer training, anger and stress management). Hacettepe University also stated that courses are promoted for language support to the staff. In regard to the course of staff management, METU and Ankara University stated that instead of contracted staff, permanent staff should be employed. Gazi University stated that the working hours are flexible. They stated that the office of Secretary General is in charge about the leaves but also the Coordinator informed, instead of this situation they said it is appropriate for permissions to be given only be the coordinators. There are different answers from universities on whether the international partners have suggestion or requests about the coordinator and staff. Gazi University stated that there are no suggestions or requests from international partners on this subject. They included that the authorized signature lists of the staff are sent National agency and they are audited from them in certain periods. Hacettepe University said that they have responsibilities for National Agency, Ministry of Finance, Internal Auditing Unit and Under secretary at of treasury. They also stated that they provide training for the domestic and foreign universities about the Program. METU said that they have a suggestion for National Agency to increase their office staff and employ permanent staff and they stated that in general there is financial control in terms of auditing. In regard to the process Ankara University said that European commission is the most effective partner about the process and the Erasmus University Declaration (2014-2020) published by the Commission is binding for them. They included that the European commission request proposal every year and publish a Program guide. In this direction, they said every country publishes an application handbook every year. They said the National Agency does this work in Turkey.

2-) Material Resources such as tools-appliances technical equipment: There are 3 questions under this title. All of the universities stated that they have sufficient tools-appliances and technical equipment and they have taken financial support from the European commission on this subject. In regard to organizational technology, all of the universities stated that usually the operations are performed via e-mail, telephone and fax machine rather than classical bureaucracy. METU said that within the institution classical bureaucracy applied such as the use of fax-machine instead of e-mail. In terms of tools - appliances requests and suggestions from 
international partners, universities said that there are no direct sanctions, expense appreciation is left to universities and they are audited in certain periods by National Agency and Internal Auditing Unit.

3-) Methods and techniques used in Administration: There are 6 questions under this category. In regard to whether there is model for the regulation created for the processing of the Program, Ankara University said that they examine the other universities' regulation and make a risk assessment and create a workflow diagram. Hacettepe University said workflow diagram books are created as a result of experiences. Gazi University said there is no handbook except for the Erasmus Hand Book. METU said there are no workflow diagrams but unwritten work calendars. In regard to regulation update universities stated that there is no need for this situation general. Ankara University said that if the regulations updates are found reasonable they are presented to the senate. Gazi University said it is presented to the Administration Committee through the rector and vice rector. METU said that the updating request is forwarded to assistant to rector over coordinator. In regard to the course of the management of the Program and the actions taken in case of the inability of the current structure, Gazi and Hacettepe Universities said that the hand book is used for the Program and all the procedures are conducted according to this guide. Ankara University said that two ways used as institutional and sympathetic to overcome adversities and received help from the vice rector. The quality of the work and processes they are doing asked to the universities among with their compatibility of the quality of the administrative structure that they are parting. They are also asked the whether they are contributing to the structure. Gazi University stated that the units are trying to keep up with the working speed of the Program and within the university those who have attended to the Staff mobility embraces the Program more. Hacettepe University said that the mobility of the administrative staff can help to provide this transformation. However, because of the unit having isolated, it has been said that it is not going to contribute to the transformation of the existing bureaucratic structure. Ankara University said that the unit is in operation as defacto and because of them not having a place in the current organization law, there are aspects of it which is not compatible existing strict bureaucratic administration. Despite this it has been said that they have contribution to the transformation of the current bureaucratic structure. For instance, working processes of the unit (regarding to academic recognition for instance) are also added to other units working processes. This situation resulted in couple of changes in the structure of the other units. It has been asked to the international partners that whether they imitate the working form and process of the office, whether they have any suggestion, request or support. Gazi University said there is no intervention of the international partners and all the suggestions are received from the National Agency. They stated that they are visited by the various domestic and foreign universities about the working processes of the unit. METU stated that the staff who has gone to abroad with mobility has seen the foreign applications and there are situations that are taken as example such as the reception services of the foreign universities. . For the Ankara University suggestions of the National agency are more likely the matter of subject. For instance there have been suggestions as to increase the number of staff. On the other hand, they said they are both taken as example and take example about the working forms from the national/international partners.

4-)Organizational Structure and Duties: There are 8 questions under this title. To the question whether the office is compatible with the organizational structure with the institutions during its constitution, Gazi, Ankara and Hacettepe universities stated that the offices are constituted defacto in the direction of the needs, on the requirements of work. To the question are the authorizations and responsibilities of the office coordinator and staff clear? Gazi University said that it is clear in the Erasmus Hand Book, Hacettepe University said there are work flow diagrams on this subject and Ankara University said there are instructions and work flow diagrams. To the question 'Are there any suggestions from the office staff, coordinators and partners about the organizational structure?' Are these suggestions taking into consideration? Hacettepe University said the suggestions and opinions are taken into consideration. Ankara University also said the suggestions are taken in to consideration. They stated that they also take the suggestions of the partners into consideration. Ankara and Hacettepe University said that on their return those who attended the mobility program write this on their final report and the office is taking this feedback into consideration. To the question what is course for office management for its conduction to be effective and clear? Hacettepe University said that personal impression reports are issued, for instance the report of the student who has gone to Germany will be examined by those who will go there next year. Gazi University said the process operates open to everybody and they are clear. Ankara University said the process is conducted in digital platform and thanks to the Mobility Tool EU commission and National Agency follow the process closely. To the question whether the quality of the Program is constraining the office working form and how the obstacles are surpassed? Ankara University said that there are disruptions due to regulation and employment types. They said it is hard to supply the dynamism that the Program needs. Hacettepe University said that the obstacles are surpassed with the help of the administrator. Gazi University said that the staff experience difficulty to adopt themselves on flexible working hours and methods (working on internet etc.) The most affected factor of the physical changes in the 
transformation of the public administration regarding its administrative structure is the human element and the organizational structure and duties that thought within the human element. When the concreted questions that are asked to the university coordinators and specialists about the human factor - evaluated, not having a certain criteria for the commissioning of the coordinator and staff who are premise in the application of the Program, the variety of the employment of the office staff, and the presence of contracted staff are the serious obstacles for the Institutionalisation of the office. Presence of the contracted staff may result in disruptions for the embracing and consistency of the work. Because of the Program's work form and structure having required the flexible working forms and hours, it is clear that it will be difficult to employ permanent staff in the classical bureaucratic structure. Because, it should be taken in to consideration that although the permanent staff receiving the same salary, having certain working hours may harm the in-house working peace. Therefore, reverse discrimination should be made with the flexible working methods (extra leave, bonus, language support etc.) to motivate the office staff. On the other hand, it is clear that presence of the staff mobility which consists the important part of the Program will help to increase the quality of the institution staff and the transformation of the institutional structure in the long-term. It is evaluated positively to consider and being clear about the suggestions and requests of the staff and partners regarding organizational structure, staff, work and operations However if it is considered that the offices are part of the classical bureaucratic structure, it is thought that this situation is representative.

Beyond the classical bureaucratic correspondences, because the structure of the program requires being independent from time and place, it is expected that preferring the use e-mail, scanner and telephone communication, even in the long-term will be required the questioning the strict corresponds rules existing on the other units.

In the field of public administration 〈Education Sector» is one of the service sectors which affecting and involving citizen and society in all. On the other hand one of the most important characteristic of the education sector which distinct it from other sectors is that the politics presented by governments in this field take an effect in the long run. Therefore, governments in the World and Turkey should adopt the populist manner and prefer not to invest on politics which they can have a result in the short-term.

In the World and Turkey it is important to support the efforts of the enhancement of national educational policy by globalization without letting it to create negative effects (danger of the melting national values by destroying them) on the education policies. It is essential to protect national education values but also to enrich the content of the Turkish Education system in an environment where it is expressed the information is universalize and the means of access to information increased as a result of the globalization. The most important way for that is to increase the quality of 〈human〉 factor whom he is the most important and most valuable component of the education system and absorbing the changes in the education sector in the world and most importantly we should be involved the process by not taking it granted but reshaping it in the national perspective within the direction of our needs.

\section{BIBLIOGRAPHY}

[1] Akbulut, Ö., (2007) Küreselleşme, Ulus Devlet ve Kamu Yönetimi, Ankara, TODAİE.

[2] Alaylığlu, R., Oğuzkan, F. (1976), Ansiklopedik Eğitim Sözlüğü, İstanbul, İnkılap ve Aka, 2. Press.

[3] Aykın, M., S., Uysal O. C. (2003) "Eğitimde Avrupa Boyutu: Socrates, Leonardo da Vinci ve Gençlik Eylem Programları" Avrupa Birliği ve Türkiye (Ed. Erdem, M.Ş., Mehter Aykın, S. Bursa, Ezgi, s.365386.

[4] Bayraktar, G. (2003) "Yeni Sağ Düşüncesinin Kamu Yönetimindeki Yansıması Olarak Yeni Kamu Yönetimi Anlayışı”, içinde Türkiye’de Kamu Yönetimi, (Ed. Burhan Aykaç, Şenol Durgun, Hüseyin Yayman), Ankara,Yarg1.

[5] Bayramoğlu, S.,(Kış-Bahar 2003), "Düzenleyici Devlet Düzenlenirken: OECD Türkiye Raporu Üzerine Eleştirel Bir Çözümleme”, Praksis, S.9.

[6] Bulut, N., (2003) Küreselleşme: Sosyal DevletinSonu mu?”, Ankara Üniversitesi Hukuk Fakültesi Dergisi, C.52, S.2.

[7] Dolowitz, D.P.,vd., (2000), Policy Transfer and British SocialPolicy, Learning fromthe USA?, USA:Open Universty Press, Philadelphia.

[8] Farazmand, A. (2001, Temmuz-Ağustos) Küreselleşme ve Kamu Yönetimi. (Çev.SevilayKaygalak), Mülkiye, S.229, C.XXV.

[9] Güler, B.A., (Eylül 1995), "Kamu Yönetimi ve Dünya Bankası”, Amme İdaresi Dergisi, C. 28, S.3, s.1929.

[10] Hall, S., Jacques, M., (1995), Yeni Zamanlar: 1990’larda Politikanın Değişen Çehresi ,İstanbul, Ayrıntı.

[11] Kapucu, N., Kösecik, M., (2003), "Ülkeler Arasında Yönetsel Reform Transferi: Yeni Kamu Yönetimi Örneği”, (Der.) M. Akif Çukurçayır, Küresel Sistemde Siyaset, Yönetim, Ekonomi, Konya, Çizgi . 
A Tool for Understanding the Transformation within Higher Education Administration Process...

[12] Payaslığlu, A.T, (2003) “İdari Reformun Sinırlılıkları”, içinde Türkiye'de Kaти Yönetimi (Ed. Burhan Aykaç, Şenol Durgun, Hüseyin Yayman), Ankara, Yargı.

[13] Özşuca, T. Ş. (2001, Ocak-Şubat) Yapıssal Uyum, Bütünleşme ve Refah Devleti. Toplum ve Hekim, C.16, S.1.

[14] Tekinalp, G.,Tekinalp, Ü., (1997) Avrupa Birliği Hukuku, İstanbul,Beta.

[15] Üstüner, Y. (2000, Eylül) Kamu Yönetimi Kuramı ve Kamu İşletmeciliği Okulu, Amme İdaresi Dergisi, C.33. S.3.

[16] YÖK. (2010). Yükseköğretimde Yeniden Yapılanma: 66 Soruda Bologna Süreci Uygulamaları. Ankara, YÖK.

[17] (http://portal.unesco.org/en/ev.phpURL_ID=13522\&URL_DO=DO_TOPIC\&URL_SECTION=201.html (Accessed 12 August, 2016)

[18] http://www.ekonomi.gov.tr/portal/content/conn/UCM/path/Contribution\%20Folders/web/Hizmet\%20Tic aret/Uluslararasi\%İliskiler/GATS/GATS\%20Amac\%20Kapsam\%20Disiplinler.docx?lve (Accessed 10 August, 2016).

[19] http://www.oecd.org (Accessed 16 September, 2016).

[20] http://www.ab.gov.tr/files/SBYPB/Egitim\%20ve\%20Kultur/web_egitim_ve_ogretim_2020_3_.pdf (Accessed 2 September, 2016)

[21] (http://www.worldbank.org/projects/search?lang=en\&searchTerm=\&tab=map\&countryshortname_exact $=$ Turkey (Accessed 6 September, 2016).

[22] http://www.ua.gov.tr (Accessed 22 September, 2016).

[23] http://www.kalkinma.gov.tr/pages/OECDTurkiyeRaporlari.aspx (Accessed 23 August,2016)

[24] http://www.bankinformationcenter.org/wp-content/uploads/2012/12/The-World-Bank-Group-andTunusia.pdf (Accessed 31 August, 2016) 